\title{
Correlation between Political News Consumption and Civic Education Students' Political Awareness
}

\author{
Vevi Sovia Noza*, Azwar Ananda, Alia Azmi \\ Civic Education Department \\ Universitas Negeri Padang \\ Padang, Indonesia \\ *vevisovianoza@gmail.com
}

\begin{abstract}
The students' habit of consuming political news has been supported and accelerated by the easiness of getting information from various media. The habit requires critical thinking and observation as well as political awareness. This study aims to determine the correlation between Universitas Negeri Padang civic education students' political news consumption and political awareness. This quantitative research selected a sample of 77 students from the population of $\mathbf{3 3 6}$ students from the academic enrollment years of 2014, 2015, and 2016 using stratified proportional random sampling. Data were collected using questionnaires and documentation study. Quantitative data were analyzed using SPSS program. The result shows that the variable of political news consumption in the motivation, environment, and frequency indicators are categorized quite good while media indicator is not quite good. The variable of political awareness in the knowledge and understanding indicators are considered good, while in the attitude and behaviour indicators are categorized quite good. Value $r_{\text {test }}>r_{\text {table }}(0.618>0.220)$, which means there is a positive influence of following political news habit on the students' political awareness. The percentage of the influence of following political news habit on the political awareness is $38,2 \%$, which means the higher the frequency of following political news, the better the political awareness will be.
\end{abstract}

Keywords-civic education students; political awareness; political news consumption; universitas negeri padang

\section{INTRODUCTION}

Nowadays news has become an integral part of people's lives. Various informative news are often sought after by the community, particularly news that is a concern and the livelihood of many people such as political news. There are numerous sources to get political news, from print media, electronic, to online media.

Political news is important for civic education students since it can help the learning process on campus, so they are always required to be politically literate. The news contribute in shaping the students' opinion, which is related to political awareness.

Students are seen to have critical and intellectual thinking that can generate great ideas and assume great roles in the society. To be able to play a role in the community, they must have a good political awareness. This students' political awareness may be influenced by many things including political news consumption. The political awareness expected here is the result of a critical study of the real condition of the government instead of media framing so that students can take appropriate measures in carrying out their roles for the nation and the state.

Previous works have analyzed the correlation between mass media and students' political participation, such as Retnawati et. al. research in Pringsewu Regency which reveals that mass media and political behavior influence high school students' participation in the election [1]. Novianasari and Samsuri's research reveals that mass media play a significant role in improving student activists' moral movement and participant type of political participation, which is also supported by the students' academic needs and political awareness [2]. Hasan's research also reveals the influence of the media towards political participation in the Banten province election among Ciputat residence [3]. This article analyzes the correlation in a more detailed description using quantitative reasoning; the pattern of students' political news consumption, particularly television, and its correlation with political awareness as it is important for civic education students.

\section{LITERATURE REVIEW}

\section{A. Mass Media Consumption}

D'Haenens categorized mass media consumption that focuses on news into several groups: the number of news read and time consumed for reading, the sequence of news read, as well as the interest in reading and the knowledge of interest. Overal, D'Haenens perceives mass media consumption from the aspects of frequency or time used for mass media consumption [4].

The individual behavior in mass media consumption is always driven by certain motives. McQuail divides the motives of individual media use into four groups, namely information motives, personal identity motives, integration motives and social interaction and entertainment motives. The information motives, among others, are as follows [5]:

- Looking for news about events and conditions related to the immediate environment, the community, and the world;

- Seeking guidance on various practical issues, opinions and matters relating to the determination of choice; 
- Satisfy one's curiosity and general interest;

- Learning, self-education;

- Gain a sense of peace through knowledge.

These motives will direct individuals' behavior in consuming the media and will affect the selective exposure of individuals to the type and content of their media consumption [6].

The habit of consuming news in the mass media is formed due to influence during children and adolescents. This habit is partly determined by personal and family factors but is largely determined by the environment in which they develop. Moreover, the environment also provides facilities and infrastructure as well as motivation and reduce obstacles or interference of the continuation of a habit [7].

\section{B. Political News}

Political news is news concerning political activities or events around the constitutional issues and all things related to the government and state affairs. Politics must be interpreted as a human effort to organize the life of the people, government, and the state in order to achieve common goals and noble ideals, namely the improvement of life or the fate of the nation [8].

Therefore, political news includes events of the nation and the state that directly affect the lives of the people. Political news becomes the main menu of media content because it influences widely and deeply the daily life of the people. The effects of political news touch private domain. There is always an emotional connection between a person and a political decision. The sense of justice regarding the political traits or developments of a country touches the heart of the people, even the world. In a democratic country, political news is a vital need for news consumers who care about the fate of the nation and the future of the country.

\section{Political Awareness}

Political awareness is an awareness of rights and obligations as citizens [9]. It includes one's knowledge, interests and concerns about the society and political environment in which he lives. Political awareness can be interpreted as a sign that citizens pay attention to their countries' problems and or development [10]. Political awareness is a variety of forms of knowledge, orientation, and values that shape the political insights of individuals, in terms of its relationship with political power [11]. Political awareness includes a comprehensive view, critical insight, a sense of responsibility and a desire to change a condition in order to realize freedom or deal with various problems of the society [11].

Based on the experts' opinions above, it can be concluded that political awareness is a psychological condition of citizens who are responsive to all matters relating to the life of the nation and the state. Political awareness is the minimum capital in living as one nation and state. Citizens should at least have adequate knowledge of the political system, so they are aware of where and how the government are moving forward to realize the noble ideals of the nation.

According to Ruslan political awareness can be achieved through several things [11]:

- Direct political direction, both through formal and nonformal channels, through political explanations, counselling efforts and direct political teaching, which are conducted by political thinkers and leaders.

- Political experience gained from political participation.

- Awareness from learning independently, for example reading newspapers and books about politics, as well as following various news events.

- Awareness born through critical dialogues.

- Political awareness which is the result of two methods; apprenticeship and generalization. This whole method will then lead someone to gain political awareness.

To measure awareness, four indicators are used: knowledge, understanding, attitude, and behavior patterns (actions) [12].

\section{METHOD}

This research used quantitative research approach with expost facto correlational type that search to explain causal relationship that is not manipulated or treated (designed and executed) by researcher and done to a program, activity, happening which have happened. There are two variables in this research; independent variable and dependent variable. The independent variable in this research is political news consumption (X) and the dependent variable is political awareness (Y).

The sample in this research is 77 students of Universitas Negeri Padang civic education department from the enrollement year of 2014, 2015, and 2016. Data was collected using questionnaire, documentation study, and literature study. The research instrument was tested first to measure the validity and reliability. The collected data was then processed using SPSS program. The correlation between variables X and Y was conducted using Pearson Product Moment correlation test.

\section{RESULTS AND DISCUSSION}

\section{A. Result}

Validity test was used to determine whether the designed instruments was feasible or instrument still needed improvement before being disseminated to the respondent. Instrument validity used product moment correlation formula [13]. If in the test result the $r_{\text {arithmetic }}>r_{\text {table, }}$ it means items are valid. If value of $r_{\text {count }}<r$ table, it means an indicator is invalid. The result of the validity test, item 18 and 22 was declared invalid so it must be removed from the next analysis. Furthermore, the reliability test showed that an instrument was quite reliable to be used as a data gathering tool because the instrument is already sufficient [14]. To test the reliability of the instrument, the researchers used the Alpha formula. 
TABLE I. RELIABILITY TEST RESULT

\begin{tabular}{|l|l|}
\hline \multicolumn{1}{|c|}{ Variabel } & Cronbach's Alpha \\
\hline Political news consumption & 0,898 \\
\hline Political awareness & 0,876 \\
\hline
\end{tabular}

The Table I above shows Alpha Cronbach coefficient of both variables are more than 0.7 , therefore the instruments are considered reliable.

TABLE II. LEVEL OF RESPONDENT ACHIEVEMENT IN THE POLITICAL NEWS CONSUMPTION VARIABLE

\begin{tabular}{|l|l|l|}
\hline \multicolumn{1}{|c|}{ Indicator } & \multicolumn{1}{c|}{ TCR \% } & \multicolumn{1}{c|}{ Category } \\
\hline Frequency & $58,3 \%$ & Quite good \\
\hline Media & $55,7 \%$ & Less good \\
\hline Motivation & $75,1 \%$ & Quite good \\
\hline Environment & $62,8 \%$ & Quite good \\
\hline
\end{tabular}

Based on Table II, it can be inferred that from the four indicators measured in the variable of political news consumption, motivation indicator becomes the highest driver in the behavior of political news consumption, then there are environmental and frequency indicators that share the same category (quite good). Media indicator gets the lowest achievement since students do not use many varieties of media; they tend to follow political news on TV and social media only, while pay less attention to other media. This is understandable because mass media consumption will always be influenced by the characteristics of audience and access opportunity on the media. In this digital age, students have the characteristics of the tendencies to access social media and they have more opportunities to use online media than other media [7]

TABLE III. LEVEL OF RESPONDENTS' ACHIEVEMENT IN POLITICAL AWARENESS VARIABLE

\begin{tabular}{|l|l|l|}
\hline \multicolumn{1}{|c|}{ Indicator } & \multicolumn{1}{c|}{ TCR \% } & \multicolumn{1}{c|}{ Category } \\
\hline Knowledge & $79 \%$ & Good \\
\hline Understanding & $79 \%$ & Good \\
\hline Attitude & $66,7 \%$ & Quitegood \\
\hline Behaviour & $68 \%$ & Quite good \\
\hline
\end{tabular}

Table III shows that from four indicators measured in political awareness variable, knowledge and understanding indicators get the highest achievement, while the attitude indicator is the lowest although the score is not so much different from the behaviour indicator behavior and still in the same category (quite good).

Furthermore, to test the correlation between the two variables, the following hypothesis were tested by determining the correlation coefficient using Pearson product moment.

$H_{0}$ : There is no positive and significant correlation between students' political news consumption and political awareness.

$H_{a}$ : There is positive and significant correlation between students' political news consumption and political awareness.

The value of correlation coefficient pearson product moment $\left(\mathrm{r}_{\text {test }}\right)$ between variable $\mathrm{X}$ and $\mathrm{Y}$ is 0,618 . To test the hypothesis, the correlation coefficient $\left(\mathrm{r}_{\text {test }}\right)$ should be compared with the criterion $\left(\mathrm{r}_{\text {table }}\right)$ at the $5 \%$ significant level with $\mathrm{n}=77$, which is 0.220 . Therefore, since the value of $r_{\text {test }}>r_{\text {table }}(0.618>0.220)$, then $\mathrm{H}_{\mathrm{a}}$ (alternative hypothesis) is accepted and $\mathrm{H}_{0}$ (null hypothesis) is rejected.

The determinant coefficient $\left(\mathrm{r}^{2}\right)$ shows how much independent variable can explain the dependent variable, determined by calculating the value of the determinant coefficient $\left(r^{2}\right)$. The result shows that the coefficient value $r$ square $\left(\mathrm{r}^{2}\right)$ is 0.382 or if presented in percentage is $38.2 \%$. This shows that the correlation of variable $X$ (political news consumption) to the variable $\mathrm{Y}$ (political awareness) is $38.2 \%$, while $61.8 \%$ are correlated with other factors such as organizational activity, experiences, learning, political experience, and various other factors which may affect political awareness.

\section{B. Discussion}

Political news consumption has become a pattern of life for civic education students as they allocate their time for that in order to understand political materials in classes. Therefore, the students can understand political symptoms and decide political choices. The classes is their motivation to consume political news.

Most students use online media and television to access political news, since they have limited resources in print media, while they can enjoy free internet in campus and they usually live in boarding houses that have TVs.

The political news consumption behaviour contributes $38.2 \%$ in shaping their political awareness. Meanwhile, the rest $61.8 \%$ is influenced by other factors such as organizational activism, learning experience, political experience, and others that can influence political awareness. It can be concluded that the more people read political news the more they are aware of political conditions, have more roles in politics, therefore their political awareness will improve.

This means that political awareness is indeed formed by self-learning, such as reading books and newspapers and everything about politics, as argued by Ruslan [11]. He also argues that political awareness can be achieved by direct political training, both formally and informally, political awareness from critical dialogue etc.

This research found that civic education students' political awareness correlates with the political news consumption. The knowledge from political news helps them understand political events and symptoms, which will lead them to make a choice as their political statement.

\section{CONCLUSION}

Based on the analysis, it can be concluded that there is a positive and significant correlation between the UNP civic education students' political news consumption and political awareness, which means the more they consume political news, they have higher level of political awareness. Further research about the influence of political news consumption and awareness of political issues as well as roles in politics is needed to improve the students' political literacy as a whole. 


\section{ACKNOWLEDGEMENTS}

This research was conducted as an undergraduate thesis of Vevi Sovia Noza and supervised by Azwar Ananda and Alia Azmi.

\section{REFERENCES}

[1] E. Retnawati, S. Irawan, and N. Yunisca, "Pengaruh Media Massa dan Sikap Politik terhadap Partisipasi Politik Siswa dalam Pemilu," Jurnal Kultur Demokrasi, vol. 3, no. 1, 2015.

[2] D.S. Novianasari, "Peran Media Massa dalam Meningkatkan Partisipasi Politik para Aktivis HMP PKn di Yogyakarta." Sosia. vol. 13, no. 2, pp. 13-29, 2016.

[3] A. Hasan, "Pengaruh Media terhadap Tingkat Partisipasi Politik (Studi Kasus Partisipasi Politik Masyarakat Ciputat pada Pilkada Propinsi Banten Tahun 2006)," (Undergraduate Thesis for Department of Islamic Political Thought, Jakarta:Universitas Islam Negeri Syarif Hidayatullah Jakarta), 2007.

[4] L. D'Haenes, J. Nicholas, and ArdHeuvelman, News in online and Print Newspaper: Differences in Reader Consumption and Recall," New Media and Society, vol. 6, no. 3, pp. s363-383, London Sage Publication, 2004.
[5] D. McQuail, McQuail's Mass Communication Theory, 5TH edition, London: Sage Publication, 2005.

[6] A.K. Ariyanti, "Hubungan Antara Tingkat Kebutuhan Konsumsi Informasi dan Kualitas Isi Media Dengan Loyalitas Pembaca (studi Pada Harian Meteor Terkait Perubahan Dari Koran Kuning ke Koran Umum," Jurnal Interaksi, 2013.

[7] U. Rusadi, "News Consumption Across Conventional Mass Media and The Internet," Jurnal Penelitian dan Pengembangan Komunikasi dan Informatika, vol. 4, no. 3, 2014.

[8] F. Yuliatun, Penggunaan Bahasa Jurnalistik Pada Tajuk Rencana Berita Politik di Surat Kabar Haluan Riau Edisi Januari 2014, (Skripsi. Pekanbaru: FDK UIN SUSKA Riau), 2014.

[9] R. Surbakti, Memahami ilmu politik. Jakarta: Grasindo, 1999.

[10] M. Budiardjo, Dasar-Dasar Ilmu Politik. Jakarta: Gramedia Pustaka Utama, 1999.

[11] U.A.M. Ruslan, Pendidikan Politik Ikhwanul Muslimin. Solo: Era Intermedia, 2000.

[12] M. Yuliantina, Pengaruh Kesadaran Politik Terhadap Partisipasi Politik Dalam Pemilihan Kepala Desa di Desa Hajimena Kecamatan Natar Kabupaten Lampung selatan. (Skripsi. Lampung: FISIP UNILA), 2016.

[13] Riduwan, Pengantar Statistika sosial. Bandung: Alfabeta, 2014.

[14] S. Arikunto, Prosedur Penelitian Suatu Pendekatan Praktik. Jakarta: Rineka Cipta, 2010. 